\title{
Effect of preoperative carbohydrate intake on inflammatory factors and clinical outcomes in elderly patients undergoing radical prostatectomy: a single-center, double-blind randomized controlled trial
}

\author{
Zhen Hu \\ Shanghai Tenth People's Hospital \\ Ji Liu \\ Shanghai Tenth People's Hospital \\ Wenchao Ma \\ Shanghai Tenth People's Hospital \\ Fen Wang ( $\square$ fenfen1007@126.com ) \\ https://orcid.org/0000-0001-9451-0578
}

Research article

Keywords: carbohydrate, radical prostatectomy, inflammatory factors

Posted Date: June 9th, 2020

DOI: https://doi.org/10.21203/rs.3.rs-26717/v1

License: (c) (1) This work is licensed under a Creative Commons Attribution 4.0 International License. Read Full License 


\section{Abstract \\ BACKGROUND}

To investigate the advantages of Carbohydrate $(\mathrm{CHO})$ in inflammatory factors, comfort and clinical outcomes in elderly patients with open radical prostatectomy.

\section{METHODS}

Patients of $\geq 65$ years old with radical prostatectomy who underwent open radical prostatectomy were randomized to the $\mathrm{CHO}$ group, placebo group, and conventional water-blocking group. Patients in the $\mathrm{CHO}$ group and placebo group received oral $\mathrm{CHO}$, $800 \mathrm{ml}$ of placebo water before surgery,and oral $\mathrm{CHO}$ and placebo water $400 \mathrm{ml} 2$ to 3 hours before surgery; the water-free group did not drink any liquid. The main test indicators are inflammatory factors, comfort and clinical outcomes.

\section{RESULTS}

28 patients in the $\mathrm{CHO}$ group, 30 in the placebo group, and 32 in the conventional water-blocking group were included in the study. The three groups matched well in age, body mass index, the grade of (American Society of Anesthesiologists)ASA, operation time, blood loss, and fluid volume.CHO reduces IL-6 of Day1 and Day7 ( $P=0.009,0.005$, respectively), IL-8 $(P=0.005)$ of Day1, Day 1, Day 3 , and Day 7 TNF $(P=0.001,0.006,0.003$ respectively) compared with the water-stopping group ; placebo water reduced Day 1 and Day 7 TNF $(P=0.005,0.038$, respectively), Day 1 of IL-8 $(P=0.045)$. CHO reduced Day3 of TNF $(P=0.026)$ compared to placebo. In the $\mathrm{CHO}$ group and the placebo group, the morning thirst scores $(0.68,1.26$, respectively) and starvation $(0.24,0.47$, respectively)were decreased. The first time to leave bed in the conventional water-blocking group (39.21 (15-93) h) was much later than in the CHO group (28.57 (10-100) h) and the placebo group (28.71 (12-70) h).

\section{Conclusion}

Compared with routine water ban, preoperative $\mathrm{CHO}$ and placebo water can reduce the levels of IL-6, IL-8 and TNF in elderly patients undergoing radical prostatectomy, which can improve the patient's preoperative comfort and shorten the patient's first time to leave bed. Compared with placebo water, $\mathrm{CHO}$ has no significant advantage in improving inflammatory factors and clinical outcomes.

\section{Background:}

As enhanced recovery after surgery (ERAS) has gained immense popularity in the modern surgical era[1-2], the intake of carbohydrate $(\mathrm{CHO})$ before the operation has become widely accepted in clinics[3-4]. $\mathrm{CHO}$ reduces insulin resistance (IR), lowers the loss of protein, and even significantly decreases hunger and anxiety before the operation without affecting gastric emptying[5]. $\mathrm{CHO}$ also restores the function of the intestinal tract early, and reduces length of stay LLOS\&[6]. Currently, although there are several studies on the effect of $\mathrm{CHO}$ on IR[7] and patient comfort[8], there are few investigations on the role of $\mathrm{CHO}$ in strengthening the immune system after the operation; moreover, clinical researchers have paid most attention to the effect of minimal invasive surgery and abnormal fasting on the functioning of the immune system after the operation.

Patients who undergo radical resection of prostate cancer are generally elderly, many of whom are older than 80 years. The general health conditions of these patients are very poor, and many complications are present. Open radical resection of prostate cancer almost requires dissection of the pelvic lymph node; the patient has to endure large surgical trauma for a long time, along with postoperative indwelling catheters. Hence, there is a strong need for accelerated rehabilitation. The purpose of the present study was to investigate the effects of $\mathrm{CHO}$ on inflammatory factors, cellular immunity, and clinical outcome in elderly patients with open radical resection of prostate cancer. The present study aimed to investigate the advantages of $\mathrm{CHO}$ in elderly patients undergoing radical resection of prostate cancer.

\section{Methods:}


Patients who underwent open radical resection of prostate cancer in the Shanghai Tenth People's Hospital were selected for this study. The inclusion criteria were as follows: elective radical resection of prostate cancer, age range from 65 to 85 years old, body

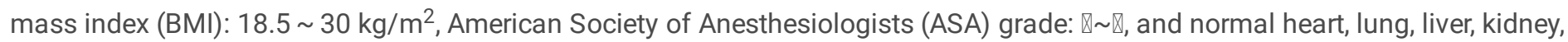
and blood coagulation function. The exclusion criteria were as follows: below 65 years of age, inability to drink transparent liquid or allergy, gastrointestinal emptying disorder or obstruction, diabetes, liver cirrhosis, severe cardiac and renal insufficiency, cortisol dosage of more than $5 \mathrm{mg} /$ day, and ASA grade III or above. The trial was approved by the Ethics Committee of the Shanghai Tenth People's Hospital, and all patients signed a written informed consent form before randomization.

The study design is shown in Fig. 1 and Flow chart is shown in Fig. 2. Patients who met the criteria were selected and randomly assigned to the $\mathrm{CHO}$ group ( $\mathrm{CHO}$ ) or placebo group (placebo) or routine water deprivation group (fasted group) according to the envelope clue. Patients and researchers were unaware of the treatment distribution. CHO (Su Qian, commonly known as maltodextrin fructose drink) and placebo products are produced by Jiangsu Zhengda Fenghai Pharmaceutical Co., Ltd., and both products have the same outer packaging. After completing data entry and database locking, the company released the product code to the researchers.

All the patients in the three groups fasted solid food for $6 \mathrm{~h}$ before the operation. From 19:00 to 24:00 on the evening before the operation, patients in the $\mathrm{CHO}$ group were given $800 \mathrm{ml}$ of a CHO drink (Su Qian contains $12.6 \% \mathrm{CHO}, 50 \mathrm{kcal} / 100 \mathrm{ml}, 290 \mathrm{mOsm} / \mathrm{kg}$, $\mathrm{pH}$ 5.0, $200 \mathrm{ml}$ per bottle). On the day of the operation, the patients in the CHO group consumed about $400 \mathrm{ml}$ of Su Qian 2 to $3 \mathrm{~h}$ before the scheduled induction of anesthesia, with an interval of more than 20 minutes. Patients in the group of placebo group were given the same amount of seasoning water at the same time (sucralose $0 \mathrm{kcal} / 100 \mathrm{ml}$, citric acid $0 \mathrm{kcal} / 100 \mathrm{ml}, 107 \mathrm{mOsm} / \mathrm{kg}, \mathrm{pH}$ 5.0), which had the same taste and appearance as the $\mathrm{CHO}$ drink. In the routine fasted group, no fluid was given before operation. To ensure the smooth implementation of the experiment, these patients were usually scheduled for the first operation on the surgery day. All operations were performed by the same group of experienced urological surgeon.

All patients received the same general anesthesia protocol, which included sufentanil, propofol, benzenesulfonic acid, and cisatracurium for general anesthesia induction and sevoflurane, propofol, remifentanil, and cisatracurium for sustaining anesthesia. After the operation, the patients were encouraged to sit by the bedside or get out of bed as soon as their health conditions permit. If there was no nausea and vomiting, the patients were asked to drink water and eat as soon as possible. Infection was defined as the presence of clinical sepsis (simultaneous presence of two or more of the following symptoms: body temperature more than $38.5^{\circ} \mathrm{C}$, heart rate of more than $100 \mathrm{bpm}$, increase in respiratory rate to more than $20 \mathrm{bpm}$, or arterial partial pressure drop below $32 \mathrm{mmHg}$ ). Antibiotics were used when the white blood cell count was more than $12 \times 10^{9} / \mathrm{I}$ or when the body temperature was more than $38^{\circ} \mathrm{C}$ for $24 \mathrm{~h}$ and no other source of fever could be detected.

At approximately 7 am before the operation, the venous blood of the patients was collected to the measure the levels of interleukin (IL), tumor necrosis factor (TNF), C-reactive protein (CRP), and cellular immunity. Venous blood samples were obtained repeatedly at the same time on days 1, 3, and 7 after the operation. In addition, the comfort and grip strength of the patients were measured at the same time before the operation and on days 1,3 , and 7 after the operation. Comfort was measured by a 100-mm visual analogue scale (VAS) [11] on the following parameters: anxiety, hunger, thirst, nausea, and fatigue. The grip strength was measured using a grip force device, and all measurements were performed using the same dominant hand. The first exhaust time, the independent standing time after surgery, the time to intake of water, and the time to intake of oral diet were recorded, and the results related to postoperative infection were assessed.

Outcome indicators:

1. Main outcome indicators: level of inflammatory markers (IL-1, IL-2, IL-6, IL-8, IL-10, TNF, and CRP).

2. Secondary outcomes: cellular immunity level (CD3, CD4, CD8, CD4/CD8, CD19, CD16/CD56), comfort (anxiety, hunger, thirst, nausea, fatigue), the index of grip strength of body mass (grip strength $(\mathrm{kg}) /$ body weight $(\mathrm{kg}) \times 100 \%$ ), clinical outcomes (first exhaust time, independent standing time after surgery, time to intake of water, time to intake of oral diet, and incidence of postoperative infection).

Statistical analysis: SPSS 19.0 statistical software was used for analysis. The measurement data of normal distribution were expressed as mean \pm standard deviation ( ), and t-test was used to compare two independent samples. For the repeated

Page $3 / 13$ 
measurement data, repeated measures analysis of variance was used to compare different time points in the group, and multivariate analysis of variance was used to compare the groups at the same time point. The measurement data of non-normal distribution were expressed as median, and the counting data were compared by the chi-square test. Differences with $\mathrm{P} \leq 0.05$ were statistically significant.

\section{Results:}

The age, BMI, ASA grade, operation time, bleeding volume, and fluid replacement volume of the three groups matched well(Table 1).

Table 1

Patient demographics and surgical characteristics

\begin{tabular}{|c|c|c|c|c|}
\hline & $\mathrm{CHO}$ & Placebo & Fasted & $p$ value \\
\hline Number of patients & 28 & 30 & 32 & \\
\hline Age at surgery(years) Mean(min-max) & $71.79(65-81)$ & $70.25(65-81)$ & $72.44(58-83)$ & 0.286 \\
\hline $\begin{array}{l}\text { BMI }\left(\mathrm{kg} / \mathrm{m}^{2}\right) \\
\text { Mean(min-max) }\end{array}$ & 23.82(17.30-31.92) & $23.97(18.51-29.76)$ & 24.16(19.00-30.76) & 0.92 \\
\hline \multicolumn{5}{|l|}{ ASA grade $(\mathrm{n} / \%)$} \\
\hline ( & $5(18)$ & $6(20)$ & $6(19)$ & \\
\hline ૧ & $17(61)$ & $18(60)$ & 19(59) & \\
\hline ૫ & $6(21)$ & $6(20)$ & $7(22)$ & \\
\hline $\begin{array}{l}\text { OR Time(min) } \\
\text { Mean(min-max) }\end{array}$ & $178.8(105-330)$ & $158.5(100-330)$ & $169.5(90-285)$ & 0.416 \\
\hline $\begin{array}{l}\text { Blood loss(ml) } \\
\text { Mean(min-max) }\end{array}$ & $189.29(50-500)$ & $225(100-900)$ & $201.56(50-500)$ & 0.628 \\
\hline Intraoperative Fluid(ml) Mean(min-max) & $2078.57(1500-3500)$ & $1925(1250-2750)$ & 2007.81(1500-2750) & 0.136 \\
\hline
\end{tabular}

It has been shown in Fig. 3 and Table 2 that compared with the routine fasted group, the CHO group showed a decreased in IL-6 on days 1 and 7, IL-8 on day 1, and TNF on days 1, 3, and 7, while the placebo group showed a decreased in TNF on days 1 and 7 and IL-8 on day 1. Compared with the placebo group, the $\mathrm{CHO}$ group showed a decreased in TNF on day 3 . No significant differences were observed in the indexes of cellular immunity among the groups. 
Table 2

The content of postoperative inflammatory factors in different groups

\begin{tabular}{|c|c|c|c|c|c|c|}
\hline & CHO Mean(SD) & $\begin{array}{l}\text { Placebo } \\
\text { Mean(SD) }\end{array}$ & $\begin{array}{l}\text { Fasted } \\
\text { Mean(SD) }\end{array}$ & $\begin{array}{l}\text { CHO vs } \\
\text { Placebo Mean } \\
\text { difference( } 95 \% \\
\mathrm{Cl}) ; \mathrm{p} \text { value }\end{array}$ & $\begin{array}{l}\text { CHO vs Fasted } \\
\text { Mean } \\
\text { difference( } 95 \% \\
\text { Cl);p value }\end{array}$ & $\begin{array}{l}\text { Placebo vs } \\
\text { Fasted Mean } \\
\text { difference( } 95 \% \\
\text { Cl);p value }\end{array}$ \\
\hline \multicolumn{7}{|c|}{ IL-6(pg/ml) } \\
\hline Day 0 & $9.6(18.29)$ & $9.09(14.58)$ & 17.1(33.58) & $\begin{array}{l}0.51(-14.32 \text { to } \\
15.35) ; 0.945\end{array}$ & $\begin{array}{l}-7.5(-21.1 \text { to } \\
6.09) ; 0.275\end{array}$ & $\begin{array}{l}-8.01(-22.14 \text { to } \\
6.11) ; 0.262\end{array}$ \\
\hline Day 1 & $72.98(58.67)$ & 109.09(116.58) & $134.6(81.28)$ & $\begin{array}{l}-36.1(-86.48 \text { to } \\
14.27) ; 0.157\end{array}$ & $\begin{array}{l}-61.62(-107.62 \text { to } \\
-15.61) ; 0.009\end{array}$ & $\begin{array}{l}-25.51(-74.37 \text { to } \\
23.34) ; 0.301\end{array}$ \\
\hline Day 3 & $27.03(39.55)$ & $33.88(38.61)$ & $33(58.92)$ & $\begin{array}{l}-6.86(-33.75 \text { to } \\
20.03) ; 0.613\end{array}$ & $\begin{array}{l}-5.98(-31.79 \text { to } \\
19.83) ; 0.646\end{array}$ & $\begin{array}{l}0.88(-25.77 \text { to } \\
27.54) ; 0.948\end{array}$ \\
\hline Day 7 & $7.9(6.27)$ & $18.29(19.95)$ & $27.49(33.83)$ & $\begin{array}{l}-10.39(-24.53 \text { to } \\
3.75) ; 0.147\end{array}$ & $\begin{array}{l}-19.59(-32.98 \text { to } \\
-6.2) ; 0.005\end{array}$ & $\begin{array}{l}-9.2(-22.59 \text { to } \\
4.19) ; 0.175\end{array}$ \\
\hline \multicolumn{7}{|c|}{ IL-8(pg/ml) } \\
\hline Day 0 & 179.23(305.38) & 181.03(376.86) & 197.96(233.26) & $\begin{array}{l}-1.81(-181.65 \text { to } \\
178.03) ; 0.984\end{array}$ & $\begin{array}{l}-18.73(-183.56 \text { to } \\
146.1) ; 0.821\end{array}$ & $\begin{array}{l}-16.92(-188.17 \\
\text { to } \\
154.32) ; 0.844\end{array}$ \\
\hline Day 1 & $253.29(444.17)$ & 406.38(665.09) & 851.78(1014.13) & $\begin{array}{l}-153.08(-601.84 \\
\text { to } \\
295.67) ; 0.499\end{array}$ & $\begin{array}{l}-598.49(-1008.32 \\
\text { to }-188.66) ; 0.005\end{array}$ & $\begin{array}{l}-445.4(-880.59 \\
\text { to }-10.22) ; 0.045\end{array}$ \\
\hline Day 3 & $344.74(618.95)$ & 466.31(714.82) & 428.44(808.19) & $\begin{array}{l}-121.56(-532.1 \\
\text { to } \\
288.97) ; 0.557\end{array}$ & $\begin{array}{l}-83.7(-477.77 \text { to } \\
310.36) ; 0.673\end{array}$ & $\begin{array}{l}37.86(-369.08 \\
\text { to } \\
444.81) ; 0.853\end{array}$ \\
\hline Day 7 & $325.83(604.03)$ & $265.24(340.08)$ & $654.45(1027.1)$ & $\begin{array}{l}60.59(-378.15 \\
\text { to } \\
499.34) ; 0.784\end{array}$ & $\begin{array}{l}-328.62(-744.05 \\
\text { to } 86.81) ; 0.119\end{array}$ & $\begin{array}{l}-389.21(-804.65 \\
\text { to } 26.22) ; 0.066\end{array}$ \\
\hline \multicolumn{7}{|c|}{ TNF(pg/ml) } \\
\hline Day0 & $14(25.01)$ & 13.83(15.14) & $20.47(12.86)$ & $\begin{array}{l}0.17(-10.65 \text { to } \\
10.99) ; 0.975\end{array}$ & $\begin{array}{l}-6.46(-16.38 \text { to } \\
3.45) ; 0.198\end{array}$ & $\begin{array}{l}-6.63(-16.94 \text { to } \\
3.67) ; 0.204\end{array}$ \\
\hline Day1 & $11.74(11.57)$ & $13.06(8.15)$ & $24.06(17.07)$ & $\begin{array}{l}-1.32(-9.11 \text { to } \\
6.46) ; 0.736\end{array}$ & $\begin{array}{l}-12.32(-19.43 \text { to } \\
-5.21) ; 0.001\end{array}$ & $\begin{array}{l}-11(-18.55 \text { to } \\
-3.45) ; 0.005\end{array}$ \\
\hline Day3 & $9.64(8.88)$ & $19.57(21.36)$ & $21.39(13.7)$ & $\begin{array}{l}-9.93(-18.61 \text { to } \\
-1.25) ; 0.026\end{array}$ & $\begin{array}{l}-11.75(-20.08 \text { to } \\
-3.42) ; 0.006\end{array}$ & $\begin{array}{l}-1.82(-10.42 \text { to } \\
6.78) ; 0.674\end{array}$ \\
\hline Day7 & $9.59(8.58)$ & $12.88(10.97)$ & 19.77(13.88) & $\begin{array}{l}-3.3(-10.19 \text { to } \\
3.59) ; 0.343\end{array}$ & $\begin{array}{l}-10.18(-16.76 \text { to } \\
-3.6) ; 0.003\end{array}$ & $\begin{array}{l}-6.88(-13.39 \text { to } \\
-0.38) ; 0.038\end{array}$ \\
\hline
\end{tabular}

It has been shown in Table 3 that compared with the routine fasted group, the $\mathrm{CHO}$ and placebo groups showed a significant decrease in the thirst score $(0.68$ and 1.26 , respectively, $P \leq 0.001)$ and hunger score $(0.24$ and 0.47 , respectively, $P<0.05)$ in the morning of the operation day, but no difference was observed in the weight grip strength index among the groups. 
Table 3

Postoperative comfort of patients in different groups

\begin{tabular}{|c|c|c|c|c|c|}
\hline & $\mathrm{CHO}$ & Placebo & Fasted & $\begin{array}{l}\text { p value(CHO vs } \\
\text { Fasted) }\end{array}$ & $\begin{array}{l}\text { p value(Placebo vs } \\
\text { Fasted) }\end{array}$ \\
\hline \multicolumn{6}{|l|}{ anxiety } \\
\hline Day 0 & $1.20(0-8)$ & $1.76(0-5)$ & $1.56(0-4)$ & 0.141 & 0.338 \\
\hline Day of surgery & $0.95(0-4)$ & $1.68(0-5)$ & $1.22(0-8)$ & 0.838 & 0.119 \\
\hline Day 1 & $0.86(0-7)$ & $0.63(0-5)$ & $0.66(0-4)$ & 0.603 & 0.999 \\
\hline Day 3 & $0.27(0-2)$ & $0.16(0-2)$ & $0.5(0-5)$ & 0.339 & 0.365 \\
\hline \multicolumn{6}{|l|}{ thirst } \\
\hline Day 0 & $1.70(0-6.5)$ & $1.42(0-5)$ & $2.38(0-5)$ & 0.451 & 0.52 \\
\hline Day of surgery & $0.68(0-4)$ & $1.26(0-4)$ & $3.03(1-8.5)$ & $<0.001$ & 0.001 \\
\hline Day 1 & $2.16(0-8)$ & $1.82(0-8)$ & $2.22(0-7)$ & 0.7 & 0.335 \\
\hline Day 3 & $1.23(0-7)$ & $0.37(0-2)$ & $0.78(0-5)$ & 0.692 & 0.306 \\
\hline \multicolumn{6}{|l|}{ hunger } \\
\hline Day 0 & $0.93(0-3)$ & $0.39(0-4.5)$ & $0.95(0-4) 0.934$ & & 0.78 \\
\hline Day of surgery & $0.24(0-3)$ & $0.47(0-3)$ & $1.39(0-7)$ & 0.004 & 0.01 \\
\hline Day 1 & $1.86(0-8)$ & $1.18(0-5)$ & $1.50(0-6)$ & 0.474 & 0.886 \\
\hline Day 3 & $0.83(0-5.5)$ & $0.42(0-5)$ & $0.89(0-5)$ & 0.889 & 0.439 \\
\hline \multicolumn{6}{|l|}{ nausea } \\
\hline Day 0 & $0(0-0)$ & $0.21(0-3)$ & $0(0-0)$ & 0.999 & 0.07 \\
\hline Day of surgery & $1.24(0-3)$ & $1.53(0-6)$ & $2(0-6)$ & 0.666 & 0.916 \\
\hline Day 1 & $0.54(0-5)$ & $1.84(0-6)$ & $1.33(0-3)$ & 0.828 & 0.758 \\
\hline Day 3 & $0.57(0-5)$ & $0.05(0-1)$ & $0.06(0-3)$ & 0.138 & 0.585 \\
\hline \multicolumn{6}{|l|}{ fatigue } \\
\hline Day 0 & $1.09(1-2)$ & $1.04(1-2)$ & $1(0-2)$ & 0.125 & 0.563 \\
\hline Day of surgery & $2.18(0-6)$ & $2.47(1-6)$ & $2.41(0-6)$ & 0.553 & 0.979 \\
\hline Day 1 & $1.63(0-7.5)$ & $0.89(0-3)$ & $1.02(0-4)$ & 0.128 & 0.786 \\
\hline Day 3 & $0.91(0-5)$ & $0.42(0-3)$ & $0.71(0-2)$ & 0.791 & 0.172 \\
\hline \multicolumn{6}{|l|}{$\begin{array}{l}\text { Grip Strength } \\
\text { Index(\%) }\end{array}$} \\
\hline Day 0 & $\begin{array}{l}44.67(29.04- \\
67.74)\end{array}$ & $\begin{array}{l}46.86(33.38- \\
67.69)\end{array}$ & $\begin{array}{l}44.07(30.71- \\
62.27)\end{array}$ & 0.211 & 0.588 \\
\hline Day of surgery & $\begin{array}{l}38.38(26.22- \\
68.06)\end{array}$ & $\begin{array}{l}41.45(32.77- \\
57.50)\end{array}$ & $\begin{array}{l}41.29(25.88- \\
57.88)\end{array}$ & 0.57 & 0.475 \\
\hline Day 1 & $\begin{array}{l}39.15(27.57- \\
65.97)\end{array}$ & $\begin{array}{l}42.14(24.80- \\
63.23)\end{array}$ & $\begin{array}{l}43.00(30.88- \\
61.21)\end{array}$ & 0.968 & 0.567 \\
\hline Day 3 & $\begin{array}{l}42.41(29.73- \\
66.13)\end{array}$ & $\begin{array}{l}44.11(25.13- \\
63.13)\end{array}$ & $\begin{array}{l}44.08(28.86- \\
64.85)\end{array}$ & 0.496 & 0.691 \\
\hline
\end{tabular}


It has been shown in Table 4 that the independent standing time after surgery of the routine fasted group was $39.21 \mathrm{~h}(15-93 \mathrm{~h})$, which was much later than those of the other two groups (CHO, 28.57 (10-100) h; placebo group, 28.71 (12-70) h). There was no difference in the first exhaust time, the time to intake of water, and the time to intake of oral diet among the three groups. Moreover, no significant difference in postoperative infection incidence was noted among the three groups within 7 days after the operation.

Table 4

Recovery of patients in different groups

\begin{tabular}{|c|c|c|c|c|c|c|}
\hline & $\begin{array}{l}\text { CHO } \\
\text { Mean(min- } \\
\text { max) }\end{array}$ & $\begin{array}{l}\text { Placebo } \\
\text { Mean(min- } \\
\text { max) }\end{array}$ & $\begin{array}{l}\text { Fasted } \\
\text { Mean(min- } \\
\text { max) }\end{array}$ & $\begin{array}{l}\text { CHO vs Placebo } \\
\text { Mean } \\
\text { difference }(95 \% \\
\text { Cl);p value }\end{array}$ & $\begin{array}{l}\text { CHO vs Fasted } \\
\text { Mean } \\
\text { difference }(95 \% \\
\text { Cl);p value }\end{array}$ & $\begin{array}{l}\text { Placebo vs Fasted } \\
\text { Mean } \\
\text { difference( } 95 \% \\
\text { Cl);p value }\end{array}$ \\
\hline $\begin{array}{l}\text { Time to first anal } \\
\text { exhaust }(h)\end{array}$ & $\begin{array}{l}24.70(5.5- \\
101)\end{array}$ & $\begin{array}{l}26.46(7.5- \\
64)\end{array}$ & $\begin{array}{l}25.02(1.5- \\
93)\end{array}$ & $\begin{array}{l}-1.76(-11.19 \text { to } \\
7.66) ; 0.711\end{array}$ & $\begin{array}{l}-0.32(-9.30 \text { to } \\
8.65) ; 0.943\end{array}$ & $\begin{array}{l}1.44(-7.91 \text { to } \\
10.79) ; 0.76\end{array}$ \\
\hline $\begin{array}{l}\text { Independent } \\
\text { standing time } \\
\text { after surgery (h) }\end{array}$ & $\begin{array}{l}28.57(10- \\
100)\end{array}$ & $\begin{array}{l}28.71(12- \\
70)\end{array}$ & $\begin{array}{l}39.21(15- \\
93)\end{array}$ & $\begin{array}{l}-1.37(-10.15 \text { to } \\
9.88) ; 0.978\end{array}$ & $\begin{array}{l}-10.64(-20.03 \text { to } \\
-1.25) ; 0.027\end{array}$ & $\begin{array}{l}-10.50(-20.29 \text { to } \\
-0.712) ; 0.036\end{array}$ \\
\hline $\begin{array}{l}\text { Time to intake of } \\
\text { water(h) }\end{array}$ & $\begin{array}{l}24.70(5.5- \\
101)\end{array}$ & $\begin{array}{l}26.46(7.5- \\
64)\end{array}$ & $\begin{array}{l}25.02(1.5- \\
93)\end{array}$ & $\begin{array}{l}-3.93(-4.56 \text { to } \\
3.78) ; 0.851\end{array}$ & $\begin{array}{l}-1.97(-5.87 \text { to } \\
1.92) ; 0.316\end{array}$ & $\begin{array}{l}-1.58(-5.69 \text { to } \\
2.53) ; 0.446\end{array}$ \\
\hline $\begin{array}{l}\text { Time to intake of } \\
\text { oral diet(h) }\end{array}$ & $\begin{array}{l}27.94(12- \\
73)^{-}\end{array}$ & $\begin{array}{l}34.82(8- \\
72)\end{array}$ & $\begin{array}{l}34.60(2.5- \\
80)\end{array}$ & $\begin{array}{l}-6.88(-16.50 \text { to } \\
2.73) ; 0.158\end{array}$ & $\begin{array}{l}-6.65(-15.72 \text { to } \\
2.40) ; 0.147\end{array}$ & $\begin{array}{l}0.22(-9.68 \text { to } \\
9.24) ; 0.963\end{array}$ \\
\hline \multicolumn{7}{|l|}{$\begin{array}{l}\text { number of } \\
\text { infection patient }\end{array}$} \\
\hline Day 1 & 4 & 4 & 3 & 0.916 & 0.554 & 0.623 \\
\hline Day 3 & 2 & 2 & 3 & 0.943 & 0.755 & 0.696 \\
\hline Day 7 & 0 & 0 & 0 & & & \\
\hline
\end{tabular}

\section{Discussion:}

The indexes of clinical evaluation of immune function are inflammatory markers (IL such as IL-2, IL-6, IL-8, and IL-10; TNF; and CRP) and cellular immunity ( $T$ cells, T helper cells, NK cells, and human leukocyte antigen DR (HLA-DR)). Usually, the decrease in inflammatory markers and the increase in the level of cellular immunity indicate a better immune function of the individual[13-14]. To reduce the incidence of postoperative complications, some studies have suggested that accelerating rehabilitation surgery, especially minimally invasive surgery [15], and unconventional fasting before operation can improve the immune function after operation, reduce the level of inflammatory response, and increase cell-mediated specific immunity. In 2006, the GERDIEN [16] team studied the effects of preoperative oral $\mathrm{CHO}$-rich liquid diet on postoperative immune function. Compared with the routine water deprivation group before operation, the oral $\mathrm{CHO}$ floating diet group did not a decrease in HLA-DR, and the body's fluid balance in this group was not significantly disturbed. This shows that preoperative oral administration of $\mathrm{CHO}$ s can avoid the subsequent immune response and reduce the occurrence of infectious complications. However, another study by Mathur showed that CRP and IL-6 levels had no effect on systemic inflammation in patients undergoing major abdominal surgery [17]. Therefore, the authors consider that there is no evidence that the $\mathrm{CHO}$ load is essential to reduce surgical stress response. Tran [18] found that the levels of IL- 6 and CRP were not affected by the preoperative use of $\mathrm{CHO}$ during coronary artery bypass grafting and spinal surgery.

The analysis of the present study showed that, in terms of the overall trend, compared with the routine fasted water group, the levels of inflammatory markers of the oral water placebo and $\mathrm{CHO}$ groups were lower, with an apparent decrease in the $\mathrm{CHO}$ group.

Compared with the routine fasted water group, the $\mathrm{CHO}$ group showed a decrease in TNF on the first, third, and seventh day after the operation, a decrease in IL- 6 on the first and sixth day after the operation, and a decrease in IL-8 on the first day after the operation. The reduction in TNF and IL-8 levels on the first and seventh day after the operation indicated that the $\mathrm{CHO}$ and placebo groups had a significant advantage in terms of reduction in postoperative inflammatory markers. $\mathrm{CHO}$ administration decreased TNF only on the third day after the operation when compared with the oral water placebo group; thus, it may not have much advantage in terms of reduction in the levels of inflammatory factors. In other words, taking a certain amount of liquid before operation, regardless of whether it is $\mathrm{CHO}$ or sweet water or other clear liquid, has a similar effect on postoperative inflammatory markers. Su Qian is an 
energy-rich carbohydrate drink, while placebo water is an energy-free clear liquid; the difference between these two drinks is that their sugar and energy content is 1 and 0 , respectively. Sugar and energy may not play an important role in regulating the levels of inflammatory markers, and the intake of a certain amount of liquid before operation may play a decisive role in postoperative outcome. Compared with routine water deprivation, the intake of a certain amount of liquid before operation can significantly reduce the level of inflammatory markers in the body. Although the IL-6, IL-8, and TNF levels showed significant differences among the three groups, no difference was noted in the indices of cellular immunity and the incidence of postoperative infection among the three groups; thus, no clinical significance of $\mathrm{CHO}$ administration could be established. Because several factors affect the incidence of postoperative infection, the present study suggests that preoperative use of liquid may not be a key factor for reducing postoperative infection incidence.

Several studies [19-20] have shown that preoperative administration of $\mathrm{CHO}$ can significantly reduce preoperative hunger and anxiety, and does not affect gastric volume. The present study found that the preoperative administration of fluid, either $\mathrm{CHO}$ or clear liquid, can significantly improve thirst and hunger scores in the early morning (usually 90 to 120 min after drinking the liquid in the morning) when compared with conventional water deprivation. A similar effect was observed for the comfort parameters on the operation day. Furthermore, perhaps drinking liquid, not necessarily $\mathrm{CHO}$, can significantly improve patient comfort.

The time of getting out of bed is affected by many factors such as medical staff education, renewal of medical cognition, patients' fear of getting out of bed, and postoperative pain. The independent standing time after surgery for the $\mathrm{CHO}$ and placebo groups for patients who got out of bed after the operation was shorter than that for the routine water deprivation group; this was a surprising result in this study. This finding shows that the intake of liquid before operation can actually lead to better clinical outcome of patients. $\mathrm{CHO}$, however, had no real advantage over the oral placebo water.

Some studies [21] have identified that the preoperative $\mathrm{CHO}$ load is associated only with a small reduction in the time of hospital stay, and has no effect on the incidence of complications. In China, the length of hospital stay is affected by many factors; therefore, the postoperative time of hospital stay was not included as a clinical outcome of this study. The present study showed that $\mathrm{CHO}$ and placebo water had the same advantage in reducing the levels of inflammatory markers, but there was no significant difference in postoperative infection incidence among the three groups. The present study has some limitations. The sample size was small, and the level of inflammatory markers was not necessarily positively correlated with the infection incidence. The effects of $\mathrm{CHO}$ or clear liquid on inflammatory markers and clinical outcomes in elderly patients who undergo major surgery thus need to be further studied.

\section{Conclusions:}

Compared with conventional water deprivation, the intake of $\mathrm{CHO}$ and oral water before operation can reduce the levels of IL-6, IL-8, and TNF in elderly patients with open radical resection of prostate cancer; improve the comfort of patients before operation; and shorten the independent standing time after surgery. Compared with placebo, $\mathrm{CHO}$ had no significant advantage in regulating the levels of inflammatory markers and improving clinical outcomes.

\section{Abbreviations}

\section{$\mathrm{CHO}$}

Carbohydrate

ASA

American Society of Anesthesiologists

ERAS

recovery after surgery

$\mathrm{IR}$

insulin resistance

LOS

length of stay

$\mathrm{BMI}$

body mass index

IL 
levels of interleukin

TNF

tumor necrosis factor

CRP

C-reactive protein

VAS

visual analogue scale

HLA-DR

leukocyte antigen DR

\section{Declarations}

Ethics approval and consent to participate: All procedures performed in studies involving human participants were in accordance with the ethical standards of Shanghai Tenth People's Hospital and with the 1964 Helsinki declaration and its later amendments or comparable ethical standards. Informed consent was obtained from all individual participants included in the study. This manuscript reporting adheres to CONSORT guidelines.

Consent for publication $\square$ Not applicable.

Availability of data and material[All data and materials obtained in this research are true and effective

Competing interests: The authors declare that they have no conflict of interest.

Funding: This study was funded by the Shanghai Science Committee Foundation (grant number 19411967700) and Natural Science Foundation of China (grant number 81472389, 81672549). Funders support the experiment.

Authors' contributions $\square Z \mathrm{H}$ completed the preliminary design of the trial, participated in the full implementation of the trial and prepared the manuscript. $J \mathrm{~L}$ was responsible for collecting the clinical data of the trial and collating and analyzing it. WCM was responsible for the mapping work. Mr. FW was responsible for supervising the full implementation of the trial and reviewing the trial. Results and manuscripts, all authors have read and approved the manuscript.

Acknowlegement⿰l would like to thank SHL, WTZ etc. who have not obtained the qualification of authors for their contributions to the preliminary planning part of this research. At the same time, I would like to thank Mr. FW again for his supervision and guidance on this research, and for the corresponding financial support.

\section{References}

[1] Bilku DK, Dennison AR, Hall TC,Metcalfe M .Role of preoperative carbohydrate loading: a systematic review. Ann R Coll Surg Engl. 2014 Jan;96(1):15-22.

[2] Weimann A, Braga M, Harsanyi L, Laviano A, Ljunggvist O, Soeters P; DGEM,Jauch KW, Kemen M, Hiesmayr JM, Horbach T, Kuse ER, Vestweber KH ; ESPEN guidelines on enteral nutrition: surgery including organ transplantation. Clin Nutr. 2006; 25:224-244.

[3] Feldheiser A, Aziz O, Baldini G, Cox BP, Fearon KC, Feldman LS, Gan TJ, Kennedy RH, Ljungqvist O, Lobo DN囚Miller T, Radtke FF囚 Ruiz Garces T囚 Schricker T, Scott MJ囚Thacker JK, Ytreb LM, Carli. Enhanced Recovery After Surgery (ERAS) for gastrointestinal surgery, part 2: consensus statement for anaesthesia practice. Acta Anaesthesiol Scand, 2016,60(3):289-334.

[4] Kehlet H, Wilmore DW. Multimodal strategies to improve surgical outcome. Am J Surg, 2002, 183(6): 630-641.

[5] Hausel J, Nygren J, Lagerkranser M, Hellstrom PM, Hammargvist F, Almstrom C, Lindh A, Thorell A, Ljunggvist O. A carbohydraterich drink reduces preoperative discomfort in elective surgery patients. Anesth Analg. 2001 Nov;93(5):1344-50.

[6] Noblett SE, Watson DS, Huong H囚Davison B, Hainsworth PJ, Horgan AF . Pre-operative oral carbohydrate loading in colorectal surgery: a randomized controlled trial. Colorectal Dis 2006; 8:563-569. 
[7] Dilmen OK, Yentur E, Tunali Y, Balci H, Bahar M. Does preoperative oral carbohydrate treatment reduce the postoperative surgical stress response in lumbar disc surgery? Clin Neurol Neurosurg. 2017 Feb; 153:82-86.

[8] Zhang Y, Min J. Preoperative Carbohydrate Loading in Gynecological Patients Undergoing Combined Spinal and Epidural Anesthesia. J Invest Surg. 2019 Jan 15:1-9.

[9] Porcaro AB, de Luyk N, Corsi P, et al. Robotic assisted radical prostatectomy accelerates postoperative stress recovery: Final results of a contemporary prospective study assessing pathophysiology of cortisol peri-operative kinetics in prostate cancer surgery. Asian J Urol. 2016 Apr;3(2):88-95.

[10] Pędziwiatr M, Pisarska M, Matłok M, Major P, Kisieleski M, Wieradk M, Natkaniec M, Budzynski P, Rubinkiewicz M, Budzynski R. Randomized Clinical Trial To Compare The Effects Of Preoperative Oral Carbohydrate Loading Versus Placebo On Insulin Resistance And Cortisol Level After Laparoscopic Cholecystectomy. Pol Przegl Chir. 2015 Aug;87(8):402-8.

[11] Hausel J, Nygren J, Lagerkranser M, Hellstrom PM, Hammargvist F, Almstrom C, Lindh A, Thorell A, Ljunggvist O. A carbohydraterich drink reduces preoperative discomfort in elective surgery patients. Anesth Analg. 2001 Nov;93(5):1344-50.

[12] Akdis M, Aab A, Altunbulakli C, Azkur K, Costa RA, Crameri R, Duan S, Eiwegger T, Eljaszewicz A, Ferstl R, Garbani M, Globinska A, Hess L, Huitema C, Kubo T, Komlosi Z, Konieczna P, Kovacs N, Kucukesezer UC, Meyer N, Morita H, Olzhausen J,OMahony, Pezer M, Prati M. Interleukins (from IL-1 to IL-38), interferons, transforming growth factor $\beta$, and TNF-a: Receptors, functions, and roles in diseases. J Allergy Clin Immunol. 2016 Oct;138(4):984-1010.

[13] Wu FP囚Sietses Cヌvon Blomberg BM, van LeeuwenPA, Meijer S, Cuesta MA囚Systemic and peritoneal inflammatory response after laparoscopic or conventional colon resection in cancer patients: a prospective邓randomized trial. Dis Colon Rectum, 2003,46 (2): 147-155】

[14] Schwenk W囚Jacobi C $₫$ Mansmann U, Böhm B, Müller JM. \Inflammatory response after laparoscopic and conventional colorectal resections-results of a prospective randomized trial囚Langenbecks Arch Surg, 2000, 385 (1): 2-9ه

[15] Veenhof AA囚Vlug MS『van der Pas MH, Sietses C, van der Peet DL, de Lange-de Klerk ES, Bonjer HJ, Bemelman WA, Cuesta MA囚 Surgical stress response and postoperative immune function after laparoscopy or open surgery with fast track or standard perioperative care: a randomized trial. Annals of Surgery, 2012ه255 (2): 216-221.

[16] Melis GC『van Leeuwen PA囚von Blomberg-van der Flier BM, Goedhart-Hiddinga AC, Uitdehaag BM, Strack van Schijndel RJ, Wuisman PI, van Bokhorst-de van der Schueren MA.A Carbohydrate-Rich Beverage Prior to Surgery Prevents Surgery-Induced



[17] Mathur S, Plank LD, McCall JL, Shapkov P, Mcllroy K, Gillanders LK, Merrie AE, Torrie JJ, Pugh F, Koea JB, Bissett IP, Parry BR. Randomized controlled trial of preoperative oral carbohydrate treatment in major abdominal surgery. Br J Surg. 2010; 97:485-94.

[18] Tran S, Wolever TM, Errett LE, Ahn H, Mazer CD, Keith M. Preoperative carbohydrate loading in patients undergoing coronary artery bypass or spinal surgery. Anesth Analg. 2013 Aug;117(2):305-13.

[19] Çakar E, Yilmaz E, Çakar E, Baydur H. The Effect of Preoperative Oral Carbohydrate Solution Intake on Patient Comfort: A Randomized Controlled Study. J Perianesth Nurs. 2017 Dec;32(6):589-599.

[20] Hausel J, Nygren J, Lagerkranser M, Hellström PM, Hammarqvist F, Almström C, Lindh A, Thorell A, Ljungqvist O. A carbohydraterich drink reduces preoperative discomfort in elective surgery patients. Anesth Analg. 2001 Nov;93(5):1344-50.

[21] Watt DG, McSorley ST, Horgan PG, McMillan DC. Enhanced Recovery After Surgery: Which Components, If Any, Impact on The Systemic Inflammatory Response Following Colorectal Surgery?: A Systematic Review. Medicine (Baltimore). 2015 Sep;94(36): e1286.

\section{Figures}




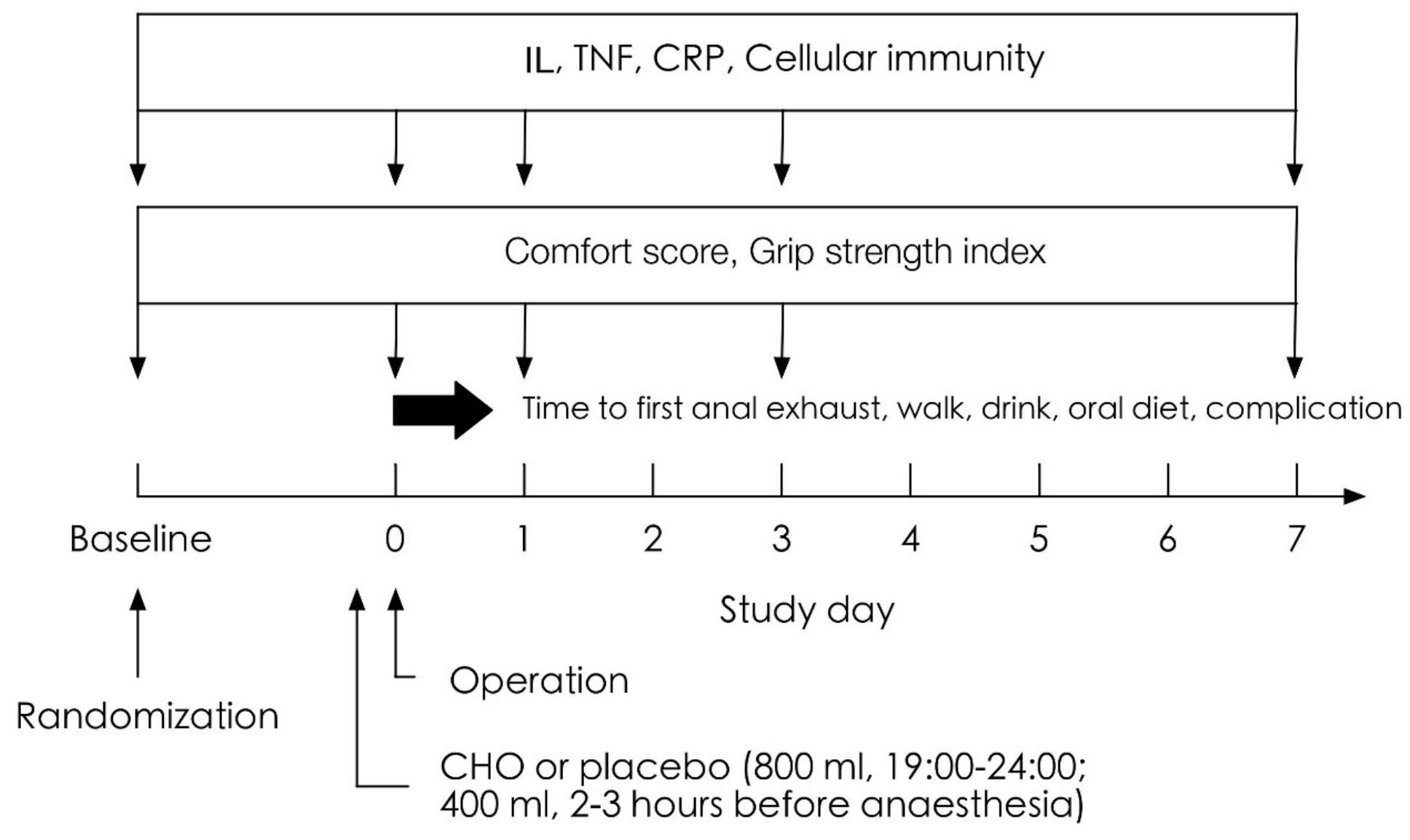

Figure 1

Illustration of the experimental design 


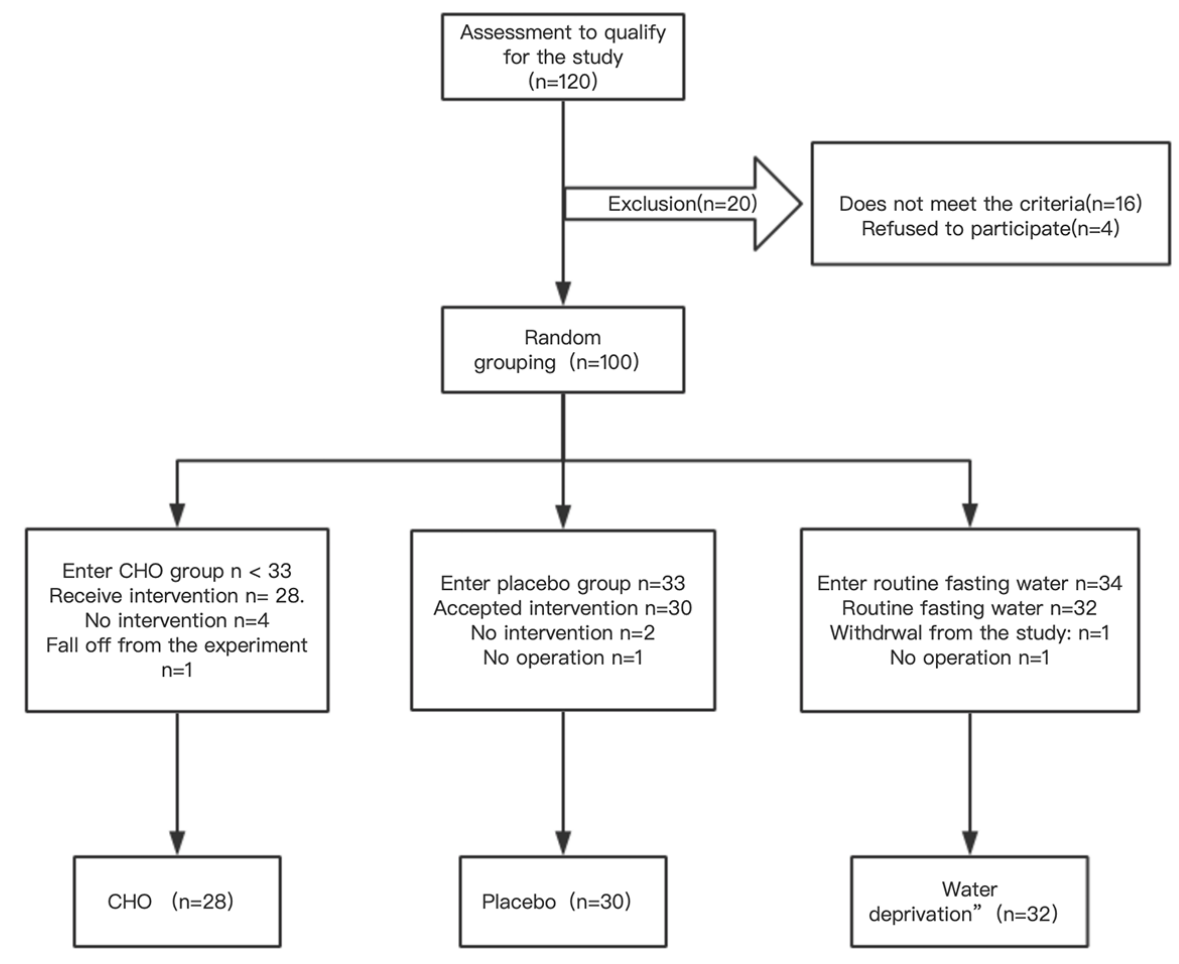

Figure 2

Experimental flow chart

A

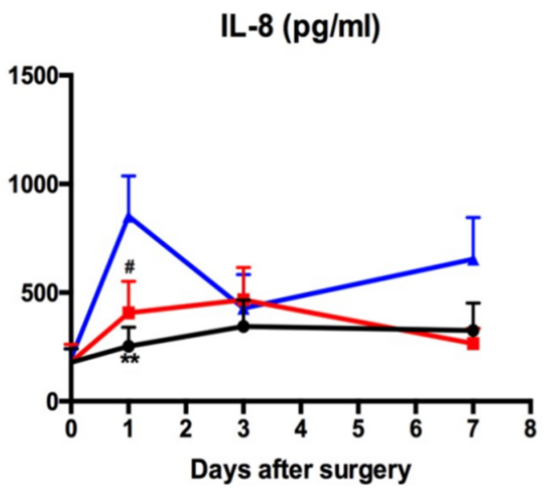

B

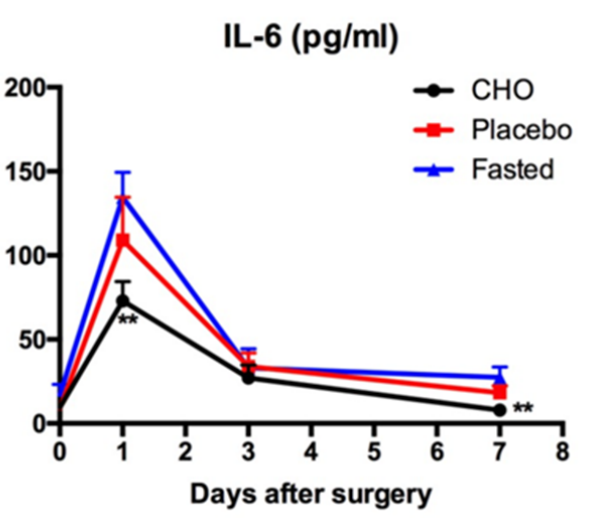

C

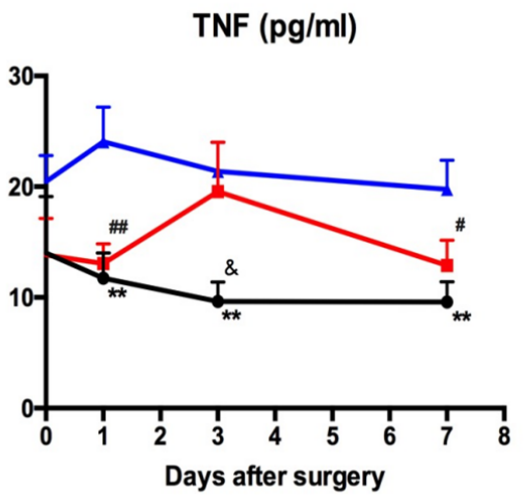

Figure 3 


\section{Supplementary Files}

This is a list of supplementary files associated with this preprint. Click to download.

- supplement1.doc 